\title{
Numerical Analysis Of Viscous Wall Dampers On Steel Frame
}

\author{
Effy Hidayaty ${ }^{1, *}$, Herlien D. Setio ${ }^{2}$, Adang Surahman ${ }^{2}$ and Muslinang Moestopo ${ }^{2}$ \\ ${ }^{1}$ Student of Doctoral Program at Faculty of Civil and Environmental Engineering, Bandung Institute of Technology \\ ${ }^{2}$ Lecturer of Doctoral Program at Faculty of Civil and Environmental Engineering, Bandung Institute of Technology
}

\begin{abstract}
The structure is designed to minimize component damaged, one of them is using a damping system. Viscous Wall Damper is one of the damping systems, using high viscosity liquids as dampers. The viscous wall damper is represented by an Exponential Maxwell Damper model. Much of the literature shows the ability of viscous wall damper by experimental studies, but few of them had discussed numerically. This article will present an analytical model of the viscous wall damper, add viscous wall damper element to an existing frame and numerical analysis. The analysis was performed by a computer application on a steel space frame that excited a combination of three earthquake types. The influence of Viscous Wall Damper showed that a significant decrement of displacement $\mathrm{u} 1$ at the structure with Viscous Wall Damper in X \& Y direction (50,78\%) and with Viscous Wall Damper in Y direction $(23,96 \%)$. The decrement displacement happened in all structure. At the end of the analysis shows the reduced of the structure periods, the structure response (displacement, velocity, and acceleration). All these results conclude that the structural components damaged due to loads can be greatly reduced.
\end{abstract}

\section{Introduction}

The basic principle of conventional earthquake resistant design that has been applied is intended to ensure an acceptable safety level while avoiding catastrophic failure and loss of life. Therefore, many types of research have been conducted into developing innovative earthquake - resistant systems in order to raise seismic performance level while keeping construction costs reasonable by using a damping system [1]. The damping system will dissipate most of the earthquake energy and less of them will transfer to the component [2]. Viscous Wall Damper (VWD) is one of the damping systems, using high viscosity liquid as dampers. The wall damper works on all of the frames, consisting of an inner plate/vane attached to the upper floor, the outer plates mounted on the lower floor, and the viscous fluid in the small gap in between. The outer plate is a kind of "house" for the inner plates. The viscous fluid is a non-toxic, odorless, transparent fluid with a viscosity of 90,000 poises [3]

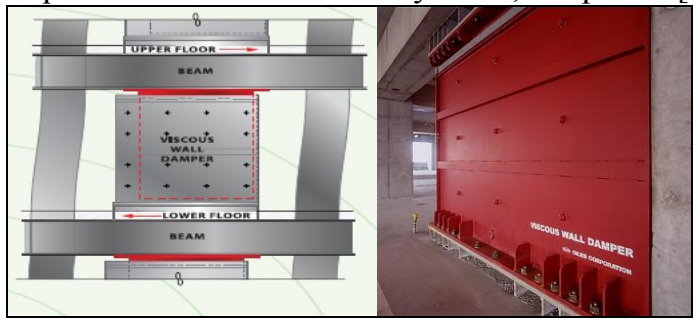

Figure 1 Viscous Wall Damper [3]

During seismic, or in strong winds excitation, the relative floor movement causes the vane move through the viscous fluid and produced a force against the inter-story drift. Thus, overall, structural deformation is reduced.

This viscous damper is a relatively new invention. Benefits of Viscous Wall Dampers are cost savings, which it reduces the weight of structural steel required and lower the total cost of the building; architectural flexibility, which the compact, rectangular shape of the damper is easier to incorporate and gives greater architectural freedom than diagonal braces or dampers; better performance, by reducing inter-story drift, the viscous wall damper provide superior seismic protection to the structure and its contents; maintenance free, the damper have no moving parts or seals, are under no internal pressure and do not require maintenance; retrofits, ideal for retrofits; easy to install and may require less structural strengthening than hydraulic damper retrofits [3].

Because of the added damping, displacements and stresses in the superstructure can be significantly reduced by up to $50 \%$, resulting in less steel and lower structural cost. This savings is more than off-sets the cost of viscous wall damper and results in a better performing and more economical structure.

The concept of a viscous wall damper was first invented by Mitsuo Miyazaki [4] (Japan) in the 1980s, studied that effectiveness of the viscous wall damper was confirmed by 5-floor model. In 1988, Miyazaki, M; Arima, F. et al., [5] stated the viscous wall damper effectively absorbs energy, thus reducing the dynamic structural response due to earthquake; also effective for structures with moderate earthquakes; more effective for stronger earthquakes; the difference of damping effect on earthquake characteristic $\mathrm{s}$ is not known on the struc- 
ture with this viscous wall damper; the acceleration and displacement of the structure may be reduced by $30 \%$ $50 \%$

Miyazaki's test of the viscous wall damper followed by Y. Matsusaka [6]; aims to produce effective dampers for weak to strong, reliable \& durable inputs, maintenance free and economical, where the target damping constants $20 \%-30 \%$ in the elastic range to reduce the dynamic response. They tested using the damper at SUT Building ( 2 basements and 14 floors) in Shizuoka, Japan. Time history analysis, the viscous wall damper matrix $\left[\mathrm{C}_{\mathrm{w}}\right]$ is added to the usual motion equation. NonNewtonian fluid effect $(\alpha<1.0)$ is given in equation 1

$$
[M]\{\ddot{x}\}+[C]\{\dot{x}\}+\left[C_{w}\right]\left\{\dot{x}^{\alpha}\right\}+[K]\{x\}=-[M]\{\ddot{z}\}
$$

By comparing the dynamic response of different structures to the seismic input conditions, it was concluded that the viscous wall damper can reduce the structure response by about $70 \%$ to $80 \%$ with the maximum response still in the elastic range. All maximum responses can be reduced to the elastic range on the frame without any damage. $[7,8]$

The reliability of the viscous wall damper was also tested by Ngai Yeung, et al. [9], to investigate the behavior and effectiveness of viscous wall damper in controlling the vibrations due to the effects of wind on high-rise buildings

Xilin Lu, et al [10] presented a thorough investigation of the viscous wall damper (VWD) for seismic response mitigation on reinforced concrete frames. The test results show a large number of additional dampers on the reinforced concrete frames of more than $20 \%$ and simultaneously drastically stiff the structure, decrease the displacement response by about $30 \%-60 \%$, the acceleration response and the reduced shear force on some cases, but increased in other cases.

The same case had been done by R Love et al [11], who had completed the construction of Hospitals in California, described an analysis of a 94,000 $\mathrm{m}^{2}$ building. He concluded that it is possible to design a very important structure in areas with high seismicity. The efficiency of the designed structural system is evidenced by the reduced tonnage of building steel.

The same state is also written by Kazuhiko Sasaki, et al. [12]. Viscous dampers are able to absorb small and large vibrational energy such as wind or seismic movement efficiently. Characteristics of viscous wall damper were designed to effectively withstand earthquakes of magnitude that have been tested and predicted for the future. The earthquake that occurred in the Tohoku Region on March 11, 2011, is stronger than predicted.

All the research improve that the viscous wall damper is able to increase the damping ratio, reduced structural response due to earthquake and wind loads, and have been widely used in tall buildings in Japan and several other countries.

Much of the literature shows the ability of viscous wall damper in experimental studies (Reinhorn AM [13], Karunarathne, et al [14]), but few of them discusses numerically, especially about how to represented and modeling of the viscous wall damper in a software. Dynamic Isolation System, as a production the viscous wall damper, had released a guideline of viscous wall damper modeling in 2015.

This research presents the numerical analysis of viscous wall damper in the steel frame, including introducing the damper, modeling, specification, implementing in 3 story steel frames, the non-linear response history analysis in steel frame without and with the damper, and the conclusion.

\section{Modeling of Viscous Wall Dampers}

The seismic response of the viscous wall dampers can be readily modeled using existing nonlinear elements in SAP2000. This section of the modeling guide is written in the context of SAP2000 and assumes that nonlinear response history analysis is performed. Dynamic Isolation System Viscous Wall Dampers are best represented by an Exponential Maxwell Damper model, as shown in the figure on the below (from the CSI Analysis Reference Manual). The SAP2000 element type is NLLINK. The model consists of a linear spring, $\mathrm{K}$, in series with an exponential damper characterized by $\mathrm{C}$ and $\alpha$, such that the force in the damper is related to the velocity across the damper through the force-velocity relationship $\mathrm{F}=\mathrm{C} \mathrm{V}^{\alpha}$ [3]. This formula is identical to apart of the formula (1).

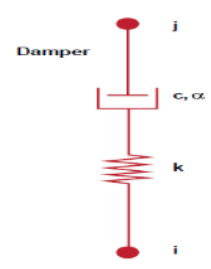

Figure 2 Modeling of Viscous Wall Dampers [3]

Unlike piston dampers, Dynamic Isolation System Viscous Wall Dampers connect to beams above and below. Therefore, to use the above 2-node element, a typical frame containing the dampers can be modeled as follows:

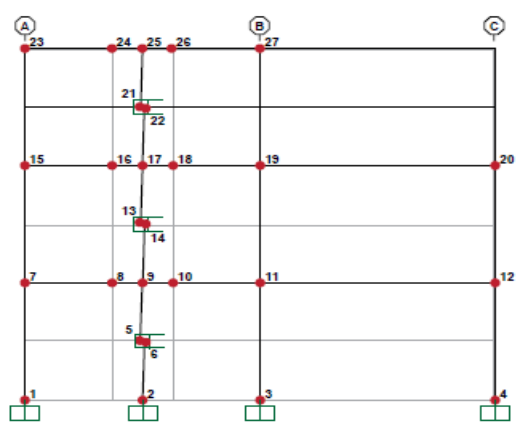

Figure 3 The Viscous Wall Damper in an existing frame [3]

\section{Application The Viscous Wall Damper on Steel Frame}


In order to verify the modeling viscous wall damper and to investigate its influence on the seismic response of a structure in a dynamic analysis, a 3D steel frame located in Yogyakarta $(-7.7956 ; 110.3695)$, Indonesia, at the soft soil.

The geometrical and mechanical properties of the frame a given in table 1 .

Table 1. Geometrical and mechanical properties of element structure

\begin{tabular}{|c|c|}
\hline \multicolumn{2}{|c|}{ Geometrical Properties } \\
\hline Element Structure & Size \\
\hline Beam & WF $300 \times 300 \times 10 \times 15$ \\
\hline $\begin{array}{l}\text { Beam which located the } \\
\text { viscous wall damper }\end{array}$ & WF $350 \times 350 \times 12 \times 19$ \\
\hline Coloum & WF $350 \times 350 \times 12 \times 19$ \\
\hline Floor & $120 \mathrm{~mm}$ \\
\hline The viscous wall damper & DIS 7'x 12' \\
\hline \multicolumn{2}{|c|}{$\begin{array}{c}\text { Mechanical Properties } \\
\end{array}$} \\
\hline Steel Frame & A572 Gr 50 \\
\hline Modulus of Elasticity (Es) & $200000 \mathrm{MPa}$ \\
\hline Yield Stress (fy) & $345 \mathrm{MPa}$ \\
\hline Ultimate Stress (fu) & $450 \mathrm{MPa}$ \\
\hline
\end{tabular}

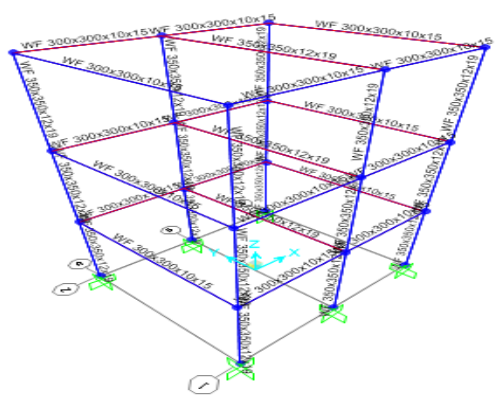

Figure 4 Numerical modeling of $3 \mathrm{D}$ three-story steel frame building

The inherent damping of a structure is assumed to be equal to $5 \%$ and VWD is added as a supplementary damping to the system. Also, velocity exponential coefficient is assumed equal to 0,5 .

Periods of fundamental approach structure Ta, was calculated as 0.195 seconds. The location of the building is in the city of Yogyakarta, which has historically experienced a major earthquake $6.2 \mathrm{Mw}$ at May 27, 2016 , with epicentre at coordinates $\left(-7.977^{\circ} ; 110.318^{\circ}\right)$ and $26 \mathrm{~km}$ from Jogyakarta city with a depth of $35 \mathrm{~km}$ due to a shift in the form of movement opposite (USGS), so the $\mathrm{R}_{\text {rupture }} 43.6 \mathrm{~km}$.

The seismic load had determined by matching the acceleration spectra at the surface from earthquake risk targeted max. consider earthquake for Yogyakarta city.

A study is presented to evaluate the effect of the viscous wall dampers on building vibration control. Therefore, the influence of the damper in the considered structure's seismic response has been investigated using a nonlinear time history analysis of the frame model under the earthquake.
Table 2. The earthquake load used in structural analysis

\begin{tabular}{|c|l|c|c|c|c|}
\hline $\begin{array}{c}\mathbf{N} \\
\mathbf{0}\end{array}$ & \multicolumn{1}{|c|}{ Location } & Year & Scale & $\begin{array}{c}\text { Mag. } \\
\text { (Mw) }\end{array}$ & $\begin{array}{c}\text { R } \\
\text { rupture }\end{array}$ \\
\hline 1 & $\begin{array}{l}\text { Imperial Valley } \\
\text { Earthquake 1940 }\end{array}$ & 1940 & 0.841 & 6.95 & 6.09 \\
\hline 2 & $\begin{array}{l}\text { Chi - chi } \\
\text { Taiwan-06 } \\
\text { Earthquake }\end{array}$ & 1999 & 1.287 & 6.3 & 43.1 \\
\hline 3 & $\begin{array}{l}\text { Iwate Japan } \\
\text { Earthquake }\end{array}$ & 2008 & 1.651 & 6.9 & 44.75 \\
\hline
\end{tabular}

\subsection{Analysis of structure without the damper}

Analysis of structure without the damper, as in figure 4.

\subsection{Analysis of structure with the dampers in $Y$ direction}

The structure used The Dynamic Isolation System Viscous Wall Dampers (DIS VWD) size 7"x 12" double vane with a viscous fluid layer thickness of $5 \mathrm{~mm}$. By using 3 dampers in the interior frame at $\mathrm{Y}$ direction, the structure had been analyzed.
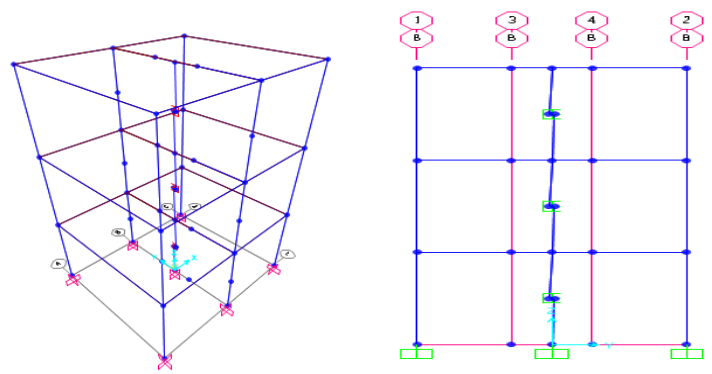

Figure 5. Structure \& numerical model with damper in $\mathrm{Y}$ direction

\subsection{Analysis of structure with the damper in $x$ and y direction}

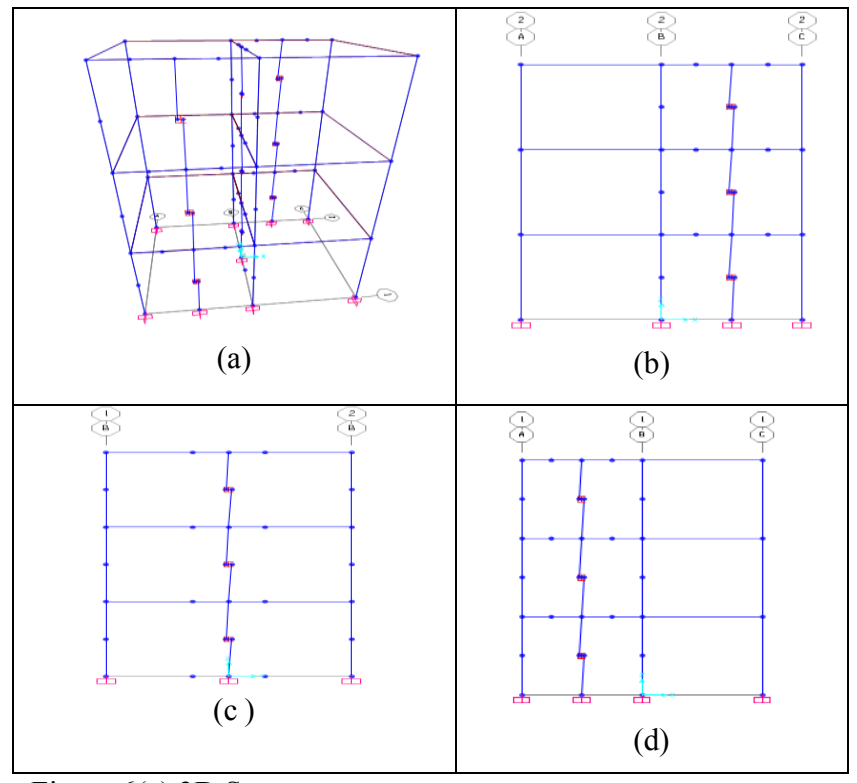

Figure 6(a) 3D Structure

(b) Frame in $\mathrm{X}$ direction $(\mathrm{y}=3.6 \mathrm{~m})$ with VWD

(c.) Frame in $Y$ direction $(\mathrm{x}=0 \mathrm{~m})$ with VWD

(d) Frame in X direction $(\mathrm{y}=-3.6 \mathrm{~m})$ with VWD 
The structure used The Dynamic Isolation System Viscous Wall Dampers (DIS VWD) size 7"x 12" double vane with a viscous fluid layer thickness of $5 \mathrm{~mm}$, the same size likes frame in $\mathrm{Y}$ direction.

By using 3 dampers in the interior frame at $\mathrm{Y}$ direction and 6 dampers in the exterior frame at $\mathrm{X}$ direction, the structure had been analyzed.

\subsection{Analysis And Discussion}

The analysis had been done by using SAP2000 version 19. The result of analysis given the following table.

Table 3 . The modal periods and eigenvalue of 3 conditions structure

\begin{tabular}{|c|r|r|r|r|r|r|}
\hline $\begin{array}{c}\text { M } \\
\text { o } \\
\mathrm{d}\end{array}$ & \multicolumn{2}{|c|}{ WITHOUT VWD } & \multicolumn{2}{|c|}{$\begin{array}{c}\text { WITH VWD IN Y } \\
\text { DIRECTION }\end{array}$} & \multicolumn{2}{|c|}{$\begin{array}{c}\text { WITH VWD IN X \& Y } \\
\text { DIRECTION }\end{array}$} \\
\cline { 2 - 7 } $\mathrm{e}$ & $\begin{array}{c}\text { Periods } \\
(\mathrm{sec})\end{array}$ & $\begin{array}{c}\text { Eigen } \\
\text { value } \\
\left(\mathrm{rad}^{2} / \mathrm{s}^{2}\right)\end{array}$ & $\begin{array}{c}\text { Periods } \\
(\mathrm{sec})\end{array}$ & $\begin{array}{c}\text { Eigen } \\
\text { value } \\
\left(\mathrm{rad}^{2} / \mathrm{s}^{2}\right)\end{array}$ & $\begin{array}{c}\text { Periods } \\
(\mathrm{sec})\end{array}$ & $\begin{array}{c}\text { Eigenvalue } \\
\left(\mathrm{rad}^{2} / \mathrm{s}^{2}\right)\end{array}$ \\
\hline 1 & 11.072 & 0.322 & 11,073 & 0,322 & 11,064 & 0,323 \\
\hline 2 & 7.895 & 0.633 & 7,267 & 0,748 & 6,999 & 0,8057 \\
\hline 3 & 6.845 & 0.843 & 6,313 & 0,991 & 4,562 & 1,897 \\
\hline 4 & 3.424 & 3.367 & 3,424 & 3.367 & 2,854 & 4,846 \\
\hline 5 & 2.387 & 6.926 & 0,835 & 56,689 & 1,700 & 13,660 \\
\hline 6 & 2.148 & 8.557 & 0,299 & 442,950 & 0,214 & 865,034 \\
\hline 7 & 0.835 & 56.687 & 0,014 & 179467,6 & 0,180 & 1214,702 \\
\hline 8 & 0.700 & 80.656 & 0,014 & 201249,1 & 0,120 & 2753,793 \\
\hline 9 & 0.295 & 453.34 & 0,014 & 201265,7 & 0,023 & 72767,976 \\
\hline
\end{tabular}

The table 3 presents the periods and eigenvalue of modal analysis of structure without VWD, with VWD on the interior frame in the $\mathrm{Y}$ direction and with VWD on the interior frame in $\mathrm{Y}$ direction \& exterior frame in the $\mathrm{X}$ direction. In general, the periods had decreased in frame with VWD, otherwise frequency angular had increased. The periods didn't have the decrease at the first time, because its need velocity to move the vane through the viscous fluid.

The last statement was proven by figure 7, that shows the structure with dampers have similar periods, especially at the higher mode (mode 2, 3, and the others). The influence of VWD also showed at table 4 , which there is a significant decrement of displacement $\mathrm{u}_{1}$ at the structure with VWD in X \& Y direction (50.78\%) and with VWD in Y direction (23.96\%). The decrement displacement happened in all structure, as table 4 presented.

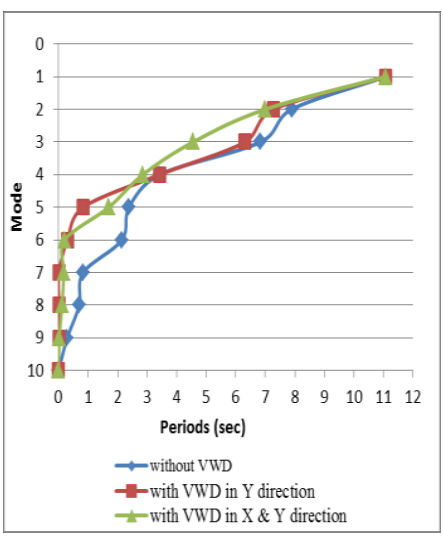

(a)

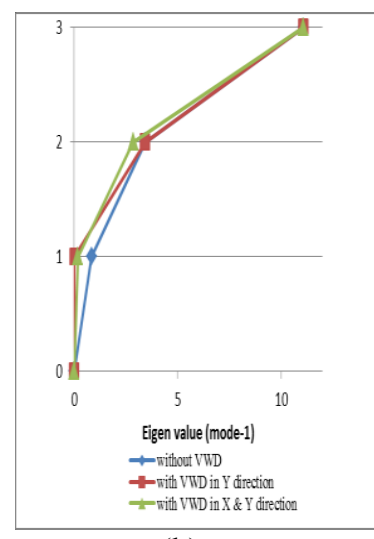

(b)
Figure 7 (a) The periods of 3 kinds of structure

(b) The Eigenvalue of them

The decrement was not happened only in the displacement, but also at the velocity, and at the acceleration, as figure 8 .

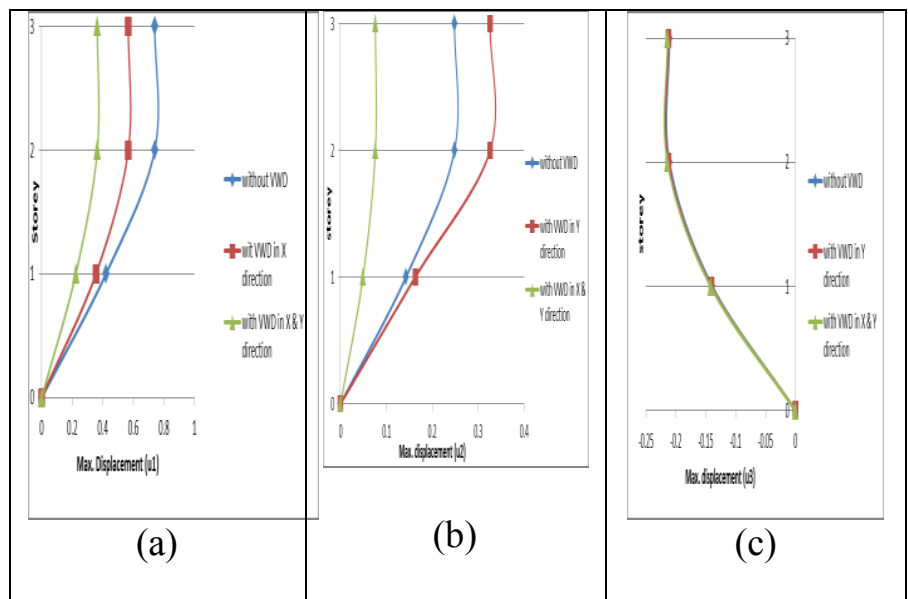

Figure 8 (a), (b), (c) The displacement u1, u2, u3 of three kinds structure respectively.

The time history analysis was conducted and the resulting peak displacements in the horizontal direction were obtained from the analysis.

Table 4. The decrement of displacement at structure with VWD

\begin{tabular}{|c|c|c|c|c|c|c|c|c|}
\hline \multirow[t]{2}{*}{ Structure } & \multirow[t]{2}{*}{ Story } & & \multicolumn{6}{|c|}{ Displacement } \\
\hline & & & U1 & U2 & U3 & R1 & $\mathbf{R 2}$ & $\mathbf{R 3}$ \\
\hline \multirow{6}{*}{$\begin{array}{l}\text { WITHOUT } \\
\text { VWD }\end{array}$} & \multirow[t]{2}{*}{3} & Max & 0.7396 & 0.2483 & -0.2105 & 0.0000 & 0.0024 & 0.0591 \\
\hline & & Min & -0.7074 & -0.2483 & -1.0535 & 0.0000 & -0.0025 & -0.0591 \\
\hline & \multirow[t]{2}{*}{2} & Max & 0.7396 & 0.2483 & -0.2104 & 0.0000 & 0.0024 & 0.0591 \\
\hline & & Min & -0.7074 & -0.2483 & -1.0535 & 0.0000 & -0.0025 & -0.0591 \\
\hline & \multirow[t]{2}{*}{1} & $\operatorname{Max}$ & 0.4207 & 0.1426 & -0.1392 & 0.0000 & 0.0018 & 0.0339 \\
\hline & & Min & -0.4100 & -0.1426 & -0.6178 & 0.0000 & -0.0019 & -0.0339 \\
\hline \multirow{6}{*}{$\begin{array}{c}\text { WITH } \\
\text { VWD IN Y } \\
\text { FRAME }\end{array}$} & \multirow[t]{2}{*}{3} & Max & 0.5666 & 0.3258 & -0.2122 & 0.0000 & 0.0019 & 0.0765 \\
\hline & & Min & -0.6070 & -0.3258 & -1.0536 & 0.0000 & -0.0021 & -0.0776 \\
\hline & \multirow[t]{2}{*}{2} & Max & 0.5666 & 0.3258 & -0.2122 & 0.0000 & 0.0019 & 0.0765 \\
\hline & & Min & -0.6070 & -0.3258 & -0.9411 & 0.0000 & -0.0021 & -0.0776 \\
\hline & \multirow[t]{2}{*}{1} & Max & 0.3553 & 0.1629 & -0.1407 & 0.0000 & 0.0015 & 0.0382 \\
\hline & & Min & -0.3478 & -0.1629 & -0.6179 & 0.0000 & -0.0015 & -0.0388 \\
\hline \multirow{6}{*}{$\begin{array}{c}\text { WITH } \\
\text { VWD IN X } \\
\& \text { Y } \\
\text { FRAME }\end{array}$} & \multirow[t]{2}{*}{3} & Max & 0.3640 & 0.0758 & -0.2142 & 0.0000 & 0.0015 & 0.0174 \\
\hline & & Min & -0.3846 & -0.0758 & -1.0537 & 0.0000 & -0.0016 & -0.0180 \\
\hline & \multirow[t]{2}{*}{2} & Max & 0.3640 & 0.0758 & -0.2142 & 0.0000 & 0.0015 & 0.0174 \\
\hline & & Min & -0.3846 & -1.0537 & -0.9412 & -0.0000 & -0.0016 & -0.0180 \\
\hline & \multirow[t]{2}{*}{1} & Max & 0.2232 & 0.0487 & -0.1418 & 0.0000 & 0.0012 & 0.0105 \\
\hline & & Min & -0.2269 & -0.0487 & -0.6179 & 0.0000 & -0.0013 & -0.0116 \\
\hline
\end{tabular}




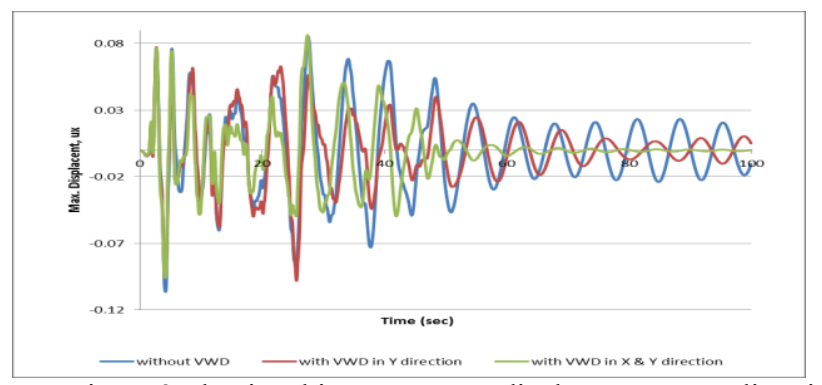

Figure 9 The time history vs max. displacement at $\mathrm{X}$ direction

This figure shows that structure with VWD in X \& Y direction had most significant decrement than the others, especially at the steady state. At transient state, the effect of dampers was not too obvious in the first 30 seconds. After that, the structures begin to vibrate regularly until it reaches steady state. The similar case also happens at maximum velocity and maximum acceleration, as figure 10 and 11 respectively

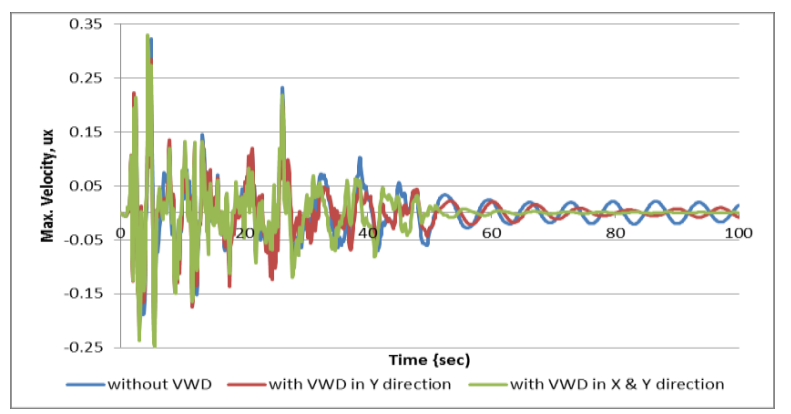

Figure 10 Time history versus max. velocity at $\mathrm{X}$ direction

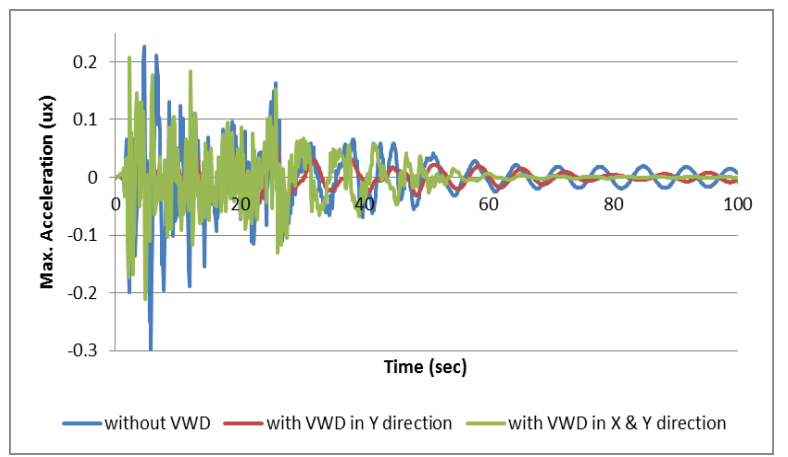

Figure 11 Time history versus max. acceleration at $\mathrm{X}$ direction

At the end, figures 9 - 11 make it obvious that the magnitude of the displacement decreased efficiently when the building was equipped with a VWD device.

\section{Conclusion}

Many efforts had been to develop the viscous wall damper as the equipment to controlled seismic response structure in experimental, but few of them had discussed numerically. A study to modeling the viscous wall damper by using existing nonlinear elements in SAP2000 had been done. It assumes that nonlinear response history analysis is performed. Dynamic Isolation System Viscous Wall Dampers are best represented by an Exponential Maxwell Damper model. The model consists of the a linear spring and in series with an exponential damper characterized by $\mathrm{C}$ and $\alpha$, such that the force in the damper is related to the velocity across the damper through the force-velocity relationship

By adding the viscous wall damper at the uncontrol structure, the analysis was performed by a computer application on a steel space frame that excited a combination of three earthquake types at a three story steel frame with equipped viscous wall dampers at interior frame $\mathrm{Y}$ direction and with viscous wall damper in $\mathrm{X} \& \mathrm{Y}$ direction

From the analysis, it displays the ability of the damper due to a relative intense earthquake load. In general, the periods had decreased in frame with VWD, otherwise frequency angular had increased. The periods didn't have decrease at the first time, because its need velocity to move the vane through the viscous fluid and produced a force against the inter-story drift.

The influence of VWD showed that a significant decrement of displacement $\mathrm{u}_{1}$ at the structure wwith VWD in X \& Y direction (50,78\%) and with VWD in Y direction $(23,96 \%)$. The decrement displacement happened at all structure

At the end, all structure analysis shows the reduction of the structure periods and the structure response (displacement, velocity, and acceleration). All these results conclude that the structural components damaged due to loads can be greatly reduced.

\section{References}

1. E. Hidayaty, H. D. Setio, Prosiding KNPTS, Peningkatan Kinerja Peredam Viskos Tipe Dinding Dengan Penambahan Kekasaran Plat Dalam Pada Struktur Baja Terhadap Beban Gempa, pp 73-81, (2016)

2. E. Hidayaty, H. D. Setio, Prosiding KNPTS, Analisis Penentuan Dimensi Plat Dalam Yang Telah Dikasarkan Pada Peredam Viskos Tipe Dinding Dalam Meningkatkan Kinerjanya Terhadap Beban Gempa, pp 67-75, (2015)

3. Dynamic Isolation System, Viscous Wall Dampers Guidelines for Modeling, (2015)

4. F. Arima F, M. Miyazaki et al, SCTRRL, Development of Viscous Damping Wall, no. 13, (1986)

5. F. Arima, M. Miyazaki et al., Proceedings of the Ninth WCEE International Association for Earthquake Engineering, Tokyo, p. 821, (1988)

6. Y. Mitsusaka; WCEE, Design of a Building with 20\% or Greater Damping, 1992 Balkema, Rotterdam, p 4143-4148, (1992)

7. F. Arima, H. Tanaka, N. Takase, H. Egasira, Nakamura, R., Miyazaki, M., and Sera, S., 1994a, SCTRRL, Experimental Study on Seismic Respons Control Technologies for Building Structures : Vibration Test for High Rise Structures using Viscous Damping Walls, (1994). 
8. F. Arima, H. Tanaka, N. Takase, H. Egasira, R. Nakamura, M. Miyazaki, and S. Sera, S., 1994b, SCTRRL, Experimental Study on Seismic Respons Control Technologies for Building Structures (Part II) : Vibration Test for High Rise Structures using Viscous Damping Walls, (1994).

9. N. Yeung N; DE Pan Austin, AYT Leung; H C Chan, Structure in The Millenium, Wind Tunnel Study Of Aeroelastic Building Model With ViscousDamping Wall For Vibration Control, , p 249 - 256, (1997).

10. L. Xilin, Z. Ying, Y. Feng, JSE, Shaking Table Test and Numerical Analysis of RC Frames with Viscous Wall Damper, Vol. 134, No. 1 January 1, 2008 (C) ASCE, ISSN 0733-9445/2008/I-64-76, (2008).

11. R. Love, S.E., J. Newell C. Poland, S.E., WCEE 13, Perfomance-Based Design of an Essential Hospital with Supplemental Viscous Damping in a High Seismic Zone, ( 2012)

12. K. Sasaki, et al, WCEE13, Characteristics of Viscous Wall Damper of Intense Oscillation Test against Large Earthquakes , (2012)

13. A. M. Reinhorn, and C. Li, NCEER, Experimental and analytical investigation of seismic retrofit of structures with supplemental damping, Part III: viscous damping walls, Technical Report NCEER95-0013, (1995).

14. N. Karunarathne. N., Catholic University of America, Damping of Frame Structure : An Educational Shake Table Test, , 2006 